\title{
Hatching rhythms and dispersion of decapod crustacean larvae in a brackish coastal lagoon in Argentina
}

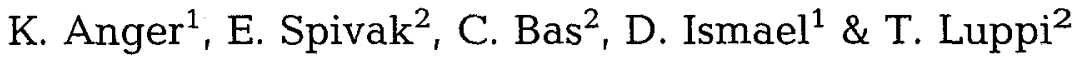 \\ ${ }^{1}$ Biologische Anstalt Helgoland, Meeresstation; D-27483 Helgoland, Germany \\ ${ }^{2}$ Departamento de Biología, Facultad de Ciencias Exactas y Naturales, Universidad \\ Nacional de Mar del Plata; 7600 Mar del Plata, República Argentina
}

\begin{abstract}
Mar Chiquita, a brackish coastal lagoon in central Argentina, is inhabited by dense populations of two intertidal grapsid crab species, Cyrtograpsus angulatus and Chasmagnathus granulata. During a preliminary one-year study and a subsequent intensive sampling programme (November-December 1992), the physical properties and the occurrence of decapod crustacean larvae in the surface water of the lagoon were investigated. The lagoon is characterized by highly variable physical conditions, with oligohaline waters frequently predominating over extended periods. The adjacent coastal waters show a complex pattern of semidiurnal tides that often do not influence the lagoon, due to the existence of a sandbar across its entrance. Besides frequently occurring larvae (exclusively freshly hatched zoeae and a few megalopae) of the two dominating crab species, those of three other brachyurans (Plathyxanthus crenulatus, Uca uruguayensis, Pinnixa patagonica) and of one anomuran (the porcellanid Pachycheles haigae) were also found occasionally. Caridean shrimp (Palaemonetes argentinus) larvae occurred in a moderate number of samples, with a maximum density of $800 \cdot \mathrm{m}^{-3}$. The highest larval abundance was recorded in $C$. angulatus, with almost $8000 \cdot \mathrm{m}^{-3}$. Significantly more $C$. angulatus and $C$. granulata zoeae occurred at night than during daylight conditions, and more larvae (statistically significant only in the former species) during ebb (outflowing) than during flood (inflowing) tides. In consequence, most crab zoeae were observed during nocturnal ebb, the least with diurnal flood tides. Our data suggest that crab larvae do not develop in the lagoon, where the adult populations live, but exhibit an export strategy, probably based upon exogenously coordinated egg hatching rhythms. Zoeal development must take place in coastal marine waters, from where the megalopa eventually returns for settlement and metamorphosis in the lagoon. Significantly higher larval frequency of $C$. granulata in low salinities ( $\leq 12 \%$ ) and at a particular sampling site may be related to local distribution patterns of the reproducing adult population. Unlike crab larvae, those of shrimp ( $P$. argentinus) are retained inside the lagoon, where they develop from hatching through metamorphosis. They significantly prefer low salinity and occur at the lagoon surface more often at night. These patterns cannot be explained by larval release rhythms like those in brachyuran crabs, but may reflect diel vertical migrations to the bottom. It is concluded that osmotic stress as well as predation pressure exerted by visually directed predators (small species or life-cycle stages of estuarine fishes) may be the principal selection factors for the evolution of hatching and migration rhythms in decapod larvae, and that these are characteristics of export or retention mechanisms, respectively.
\end{abstract}

\section{INTRODUCTION}

Euryhaline marine invertebrates living in brackish coastal lagoons represent suitable models for the study of life cycle adaptations to estuarine conditions. Grapsid crabs which are among the most typical inhabitants of such transitional ecosystems world-wide, have 
shown a particular capacity for invading brackish, freshwater, and terrestrial environments (Hartnoll, 1988). Two grapsid species, Cyrtograpsus angulatus and Chasmagnathus granulata, are the most conspicuous intertidal benthic invertebrates of temperate coastal lagoons in eastern South America; their name, "cangrejal" (from Spanish cangrejo $=\mathrm{crab}$ ), has been given to this particular type of brackish salt marsh ecosystem (Boschi, 1964, 1988). Mar Chiquita Lagoon ("Little Sea") in the Province of Buenos Aires, Argentina, is one of the southermost "cangrejal" environments, where they are found in dense populations, co-existing with a few other euryhaline marine crab species, namely another grapsid, Cyrtograpsus altimanus, a xanthid mud crab, Plathyxanthus crenulatus, and a fiddler crab, Uca uruguayensis. The only other decapod crustacean species found in this lagoon is a palaemonid shrimp, Palaemonetes argentinus, which lives mostly in the freshwater and brackish-water parts of this lagoon.

A first account of the ecology of the dominant decapod species in Mar Chiquita Lagoon, Cyrtograpsus angulatus and Chasmagnathus granulata, was given by Spivak et al. (1994), who described their habitat preferences and local distribution. However, little is known about the life cycles of these widely distributed and locally extremely abundant crustaceans. Two alternative principal strategies of dispersal and recruitment are known: some estuarine and other brackish-water inhabiting decapod species retain their larvae within the system where the adult population is found (Sandifer, 1973, 1975; Cronin, 1982; Morgan, 1987a), whereas others reveal export mechanisms and develop outside the parent environment, i. e. in coastal shelf or oceanic waters (Sandifer, 1975; Christy \& Stancyk, 1982; Truesdale \& Andryszak, 1983; Morgan, 1987a). In the latter case, recruitment depends on the re-immigration of benthic (megalopa, juvenile, or adult) life stages. In the present investigation, the occurence of larval decapod crustaceans in the plankton was studied in order to ascertain the type of development and the mechanisms of dispersal in dominating species.

\section{THE STUDY ARÈA}

Mar Chiquita is a shallow lagoon that covers $46 \mathrm{~km}^{2}$, extending from $37^{\circ} 32^{\prime}$ to $37^{\circ} 45^{\prime} \mathrm{S}$, and from $57^{\circ} 19^{\prime}$ to $57^{\circ} 26^{\prime} \mathrm{W}$. Its greatest water depth is about $1.2 \mathrm{~m}$ below the mean spring low-tide level (Argentine Hydrographic Survey Chart Nr. 29, quoted by Fasano et al., 1982). A few small rivers feed it constantly with freshwater, while seawater enters and leaves it periodically with semidiurnal high tides, passing over a shallow sandbar that is located in the mouth of the lagoon. The extent of this exchange of water depends on the tidal amplitude and winds (Olivier et al., 1972). Before the freshwater creeks enter the lagoon, they all pass a pleistocene coastal flat of marine origin which contains remains of fossil sea shells and other deposited minerals (Fasano et at., 1982). The inflowing freshwater already contains some salts (salinity: $0.96 \pm 0.05 \%$; $n=5$ ); according to the Venice classification system, it should therefore actually be called "oligohaline" (Remane, 1971). An average salinity of $33.5 \pm 1.3 \%$ n $(n=8)$ was measured in the coastal seawater entering the mouth of the lagoon.

The tidal cycle in the study area shows a rather complicated pattern of interfering tidal waves, whereby normally, one tidal cycle with high amplitude (up to ca $1.6 \mathrm{~m}$ ) follows another with low amplitude (minimum ca $0.3 \mathrm{~m}$ ). Figure 1 shows, as an example of this particular type of tide cycle pattern, one lunar cycle at Mar del Plata (tide tables 


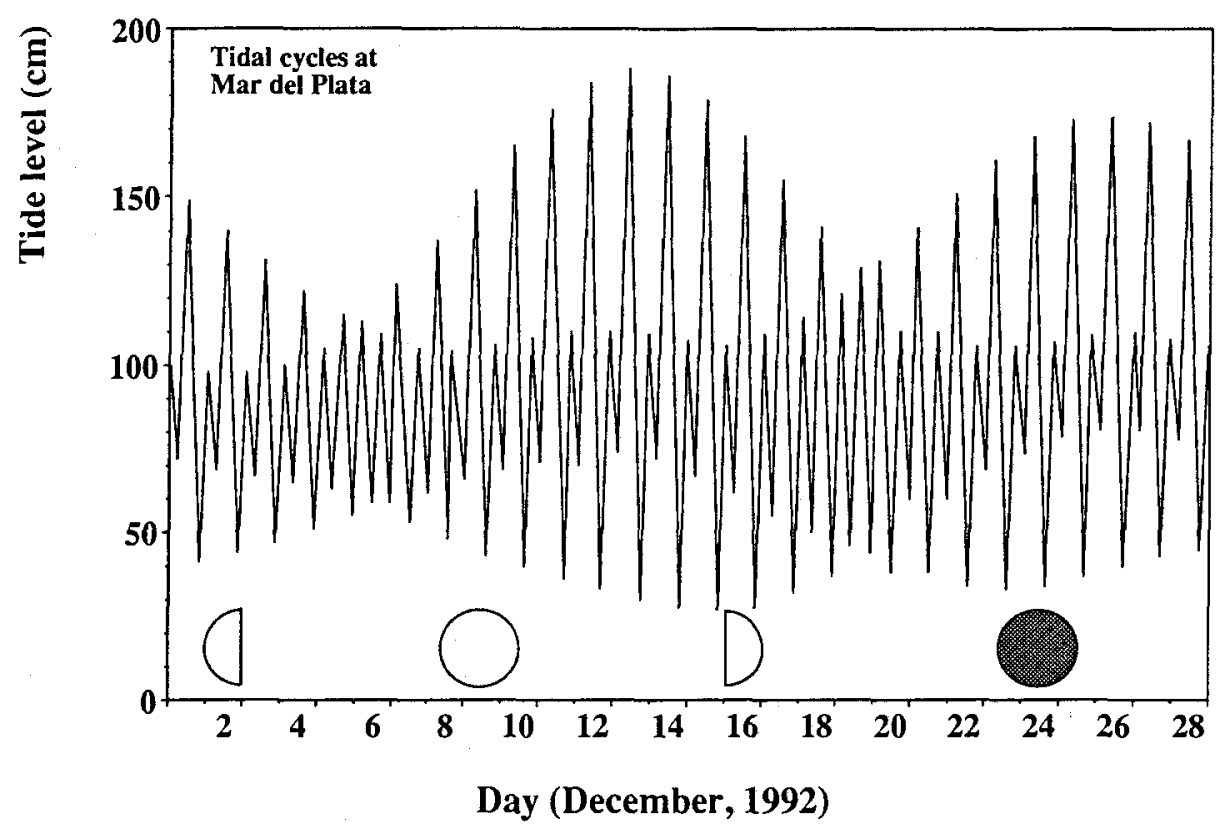

Fig. 1. Tides over one lunar cycle in December 1992 at Mar del Plata, Argentina. Times and heights taken from tide tables published by the Argentine Naval Hydrological Service

published by the Argentine Naval Hydrological Service). The difference in amplitude between two subsequent cycles is highest one half of a week after a full or new moon. Tidal amplitudes become uniformly low (about $0.5 \mathrm{~m}$ ) one week later. This pattern is modified not only by wind action, but also by the sandbar threshold in the entrance of the lagoon, which does not allow the intrusion of seawater with weak high-tides. Since a weak high-tide is followed by an ebb-tide (and sometimes later by another weak hightide), the lagoon may stay under conditions of low salinity or even freshwater for quite a long time (up to one or two days). Variations in rainfall and, hence, inflow of freshwater, will further modify the hydrographical situation.

Spivak et al. (1994) investigated habitat preferences of the two dominating decapod species, Cyrtograpsus angulatus and Chasmagnathus granulata, describing sediment and water characteristics at seven different sampling sites in the lower parts of Mar Chiquita Lagoon. Two of these sites (No. 2 and 3) were chosen also in the present study. Site 2 is an intertidal mud flat with a concrete mole and artificially placed boulders. It is located near the mouth of the lagoon ( $450 \mathrm{~m}$ distance), where both $C$. angulatus and Ch. granulata occur together in high densities, the former species being more frequent than the latter. Both species coexist also at Site 3 , but with an inverse pattern of dominance. The latter sampling site is also a mud flat, $1.5 \mathrm{~km}$ from the mouth of the lagoon, showing more estuarine influence than Site 2 (see below, Fig. 2). Fiddler crab (Uca uruguayensis) populations occur at both sites, whereas mud crabs (Plathyxanthus crenulatus) and another grapsid species (Cyrtograpsus altimanus) were found only at Site 2. Adult shrimps (Palaemonetes argentinus) were not found at either site, since this 


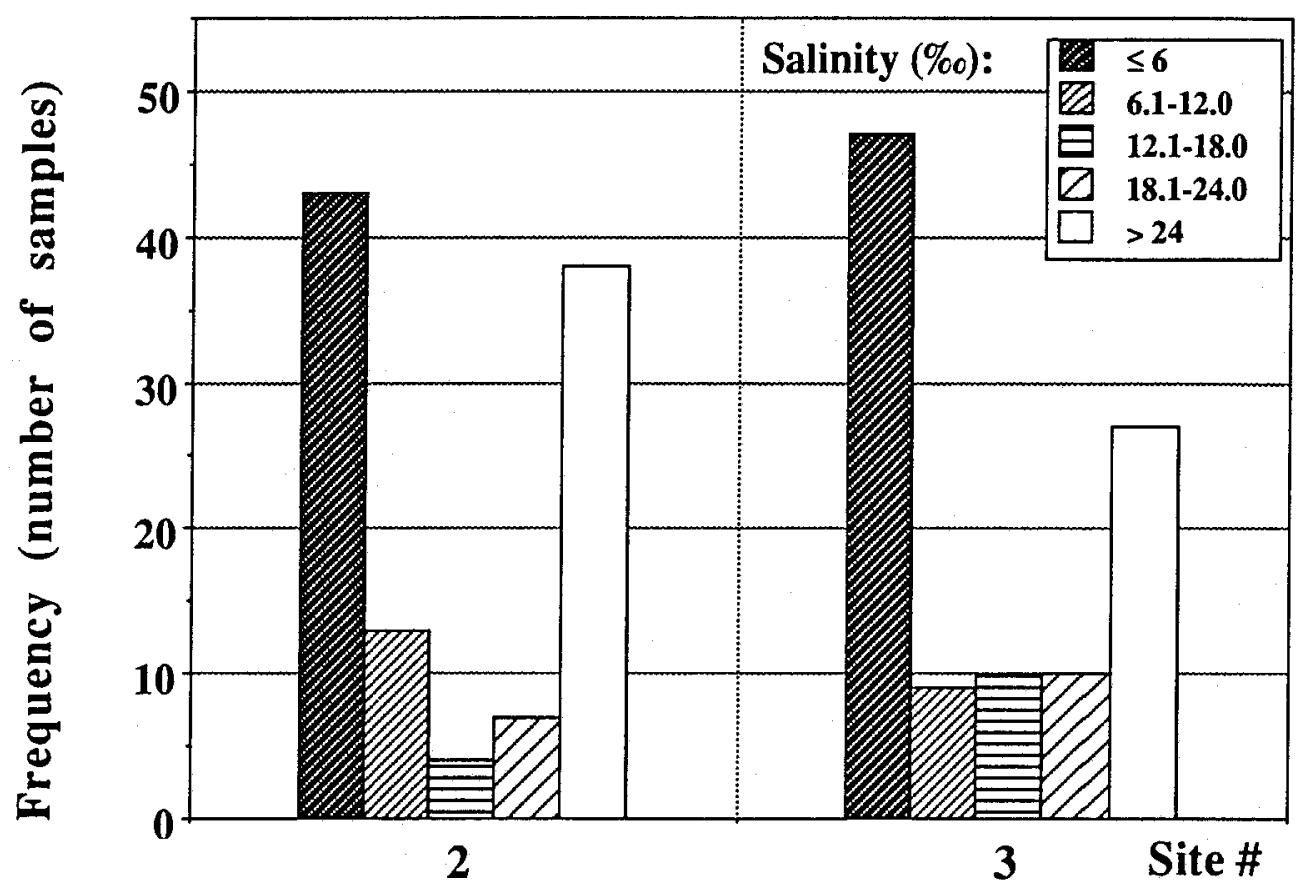

Fig. 2. Frequency of different salinity classes in water samples taken in November-December 1992 in Mar Chiquita Lagoon, Argentina, at two different sampling sites

species prefers less saline conditions, such as those prevailing in the innermost parts of the lagoon and in adjacent freshwater creeks.

\section{MATERIALS AND METHODS}

Time and height of oceanic tides outside Mar Chiquita lagoon were estimated from data registered at the nearest hydrographical station (Mar del Plata, $35 \mathrm{~km}$ of south of Mar Chiquita), 45 minutes being added to the time tables given for Mar del Plata. The actual tide levels within Mar Chiquita Lagoon were measured at Site 2, where watermarks could be read on the vertical wall of a concrete mole. The zero of this scale was defined arbitrarily, corresponding to the lowest registered level. Data on moon phases and daylengths (hours of sunrise and sunset, for the definition of day and night samples) were taken from the 1992 nautical tables edited by the Bundesamt für Seeschiffahrt und Hydrographie (1991).

Plankton and water samples were taken in nearshore waters from the surface of the lagoon (water depth of sampling sites: $20-40 \mathrm{~cm}$ ), employing a marked 5-litre plastic container. Ten samples (in total 501 ) were subsequently passed through a sieve with $300 \mu \mathrm{m}$ mesh size. Macrozooplankton was rinsed into smaller (0.5 l) sample bottles, and later examined under a stereo microscope. Temperature was measured in situ (precision $\pm 0.1^{\circ} \mathrm{C}$ ). Salinity (converted from conductivity measurements after appropriate calibra- 
tion) and $\mathrm{pH}$ were measured by means of a Jenway 3405 portable electrochemistry analyser in water samples $(100 \mathrm{ml})$.

Decapod larvae were identified using the morphological descriptions given by Boschi et al. (1967) for Chasmagnathus granulata, by Menú-Marque (1973) for Palaemonetes argentinus, and by Boschi (1981) for other decapod species. In Cyrtograpsus angulatus, no description was available. Generic identification was possible by comparison with the description given by Scelzo \& Lichtschein (1979) for Cyrtograpsus altimanus. However, a safe separation of Cyrtograpsus species was not possible in this way. Since $C$. altimanus has only a very small, numerically insignificant population in Mar Chiquita Lagoon, we attributed all Cyrtograpsus larvae to C. angulatus, neglecting C. altimanus. The developmental stage within the moult cycle was determined following the classification given by Drach (1939) and described in detail for crab larvae by Anger (1983).

During a preliminary investigation (November 1991 to April 1992, June and October 1992), 196 samples were taken from various parts of Mar Chiquita Lagoon. Since this preliminary survey showed that the hydrographical conditions in the lagoon are extremely variable and complicated, the original investigation plan (to compare a series of sampling sites that should represent a permanent physical gradient within the lagoon) had to be abandoned. Instead, sampling Sites 2 and 3 (numbering according to Spivak et al., 1994) were chosen for a more intensive study, including night-time sampling. From 17 th November to 14 th December, 1992, a total of 202 water and plankton samples was taken. On four days (17th/18th, 22nd/23rd, and 29th/30th Nov., 6th/7th Dec., 1992), samples were taken at short-term (1-3 h) intervals over 30-36 hours. The first and the third of these samplings were done when particularly high and low tidal amplitudes followed each other in subsequent cycles, the second and the fourth sampling during situations with low and comparatively even tidal amplitudes (Figs 4-7; cf. Fig. 1).

Statistical analyses and tests were carried out after Sokal \& Rohlf (1981). They included least-square linear regression, goodness-of-fit G-tests, and $\mathrm{R} \times \mathrm{C}$ G-tests of independence (with William's correction).

\section{RESULTS}

\section{General hydrographical conditions}

As a consequence of a peculiar tide cycle pattern, and due to the existence of further complicating factors in the study area (Fig. 1; see above), our preliminary plankton survey showed extreme small-scale and short-term variations in physical factors and plankton composition, both during tidal cycles and in relation to meteorological conditions. On days with low tidal amplitudes, particularly when these were combined with winds from W or NW, practically no seawater entered at high tide. The water in the lagoon remained then low in salinity $(<5 \%$ ), high in $\mathrm{pH}(<8.5)$, and harboured brackish-water plankton (mostly cladocerans and ostracods). On other days, great amounts of seawater of $>30 \%$ salinity, with $\mathrm{pH}$ values around 8 , and coastal marine plankton (mostly dominated by calanoid copepods) entered the lagoon with spring high-tides. When these were enhanced by easterly winds, highly saline water masses advanced up to several kilometres into the lagoon. 
Due to apparently restricted mixing processes, these physically and biologically very different water bodies (often distinguishable by their differing coloration) could co-exist for many hours within the lagoon. Tidal movements of these water masses caused drastic small-scale and short-term variation in hydrographical conditions, sometimes changing within one or two hours from oligohaline to seawater, or vice versa. On the other hand, persistence of water bodies over extended periods ( $>1$ day) could lead to the seemingly paradox situation that oligohaline water dominated near the mouth of the lagoon (even during high tide), while other sites far "upstream", in particular blind-ending tidal creeks in the inner parts of the lagoon, remained with much higher salinities, lower $\mathrm{pH}$, and with marine plankton.

Persistence rather than mixing of water bodies is indicated also by the frequency pattern of salinities measured in our samples (Fig. 2). At both study sites, they showed a pronounced bimodal distribution, with oligohaline $(\leq 6 \%)$ and polyhaline to euhaline $(>24 \%)$ waters clearly dominating over intermediate $(>6-24 \%)$ conditions. Very low salinities were observed more frequently at Site 3 , while polyhaline and euhaline conditions occurred less frequently at Site 3 than at Site 2 (Fig. 2). Thus, the former site had, on the average, a more estuarine character; however, extreme variability was typical of both sampling sites.

The data obtained from different sampling sites, tides, seasons, and day-times, including those from our preliminary survey, showed a negative correlation between salinity and $\mathrm{pH}$ values $(\mathrm{P}<0.001$; Fig. 3). Thus, $\mathrm{pH}$ might be a useful additional physical indicator for the identification of water bodies within the lagoon. However, a different type of relationship (a positive correlation) might exist in the very low salinity range $<5 \%$ and, hence, our regression line may not be valid in oligohaline water.

\section{Changes in hydrographical conditions and in the occurrence of crab larvae during tidal cycles}

Crab larvae were present in the plankton of Mar Chiquita Lagoon from October to April, with Cyrtograpsus angulatus and Chasmagnathus granulata consistently dominating. Larvae of the freshwater shrimp Palaemonetes argentinus were also found frequently, but seldom in great numbers (maximum: 800 individuals $\cdot \mathrm{m}^{-3}$ on 30 th November, 5 a.m., at Site 2, with $2.1 \%$ and a pH of 8.8). Occasionally, single or a few zoea-I larvae of a mud crab, Plathyxanthus crenulatus (Xanthidae), a fiddler crab, Uca uruguayensis (Ocypodidae), a pea crab, Pinnixa patagonica (Pinnotheridae), and of one anomuran species, Pachycheles haigae (Porcellanidae), were found.

During the entire investigation (including the preliminary one-year survey), crab larvae occurred exclusively as freshly hatched zoea I or, in a few cases, as megalopae, whereas shrimp (Palaemonetes argentinus) larvae were present at all developmental stages. Crab zoeae that had developed beyond stage $C$ (intermoult) of their first moult cycle were never found, and only exceptionally was food observed in their intestine. These facts indicate that brachyuran larvae (this applies to all species found) must leave the lagoon system very rapidly, probably within one day. When the tidal amplitude was very low, so that water exchange with the sea was correspondingly weak or lacking, and salinity remained low $(<5 \%$ ), moribund or dead crab larvae were often observed floating in the stagnant water. 


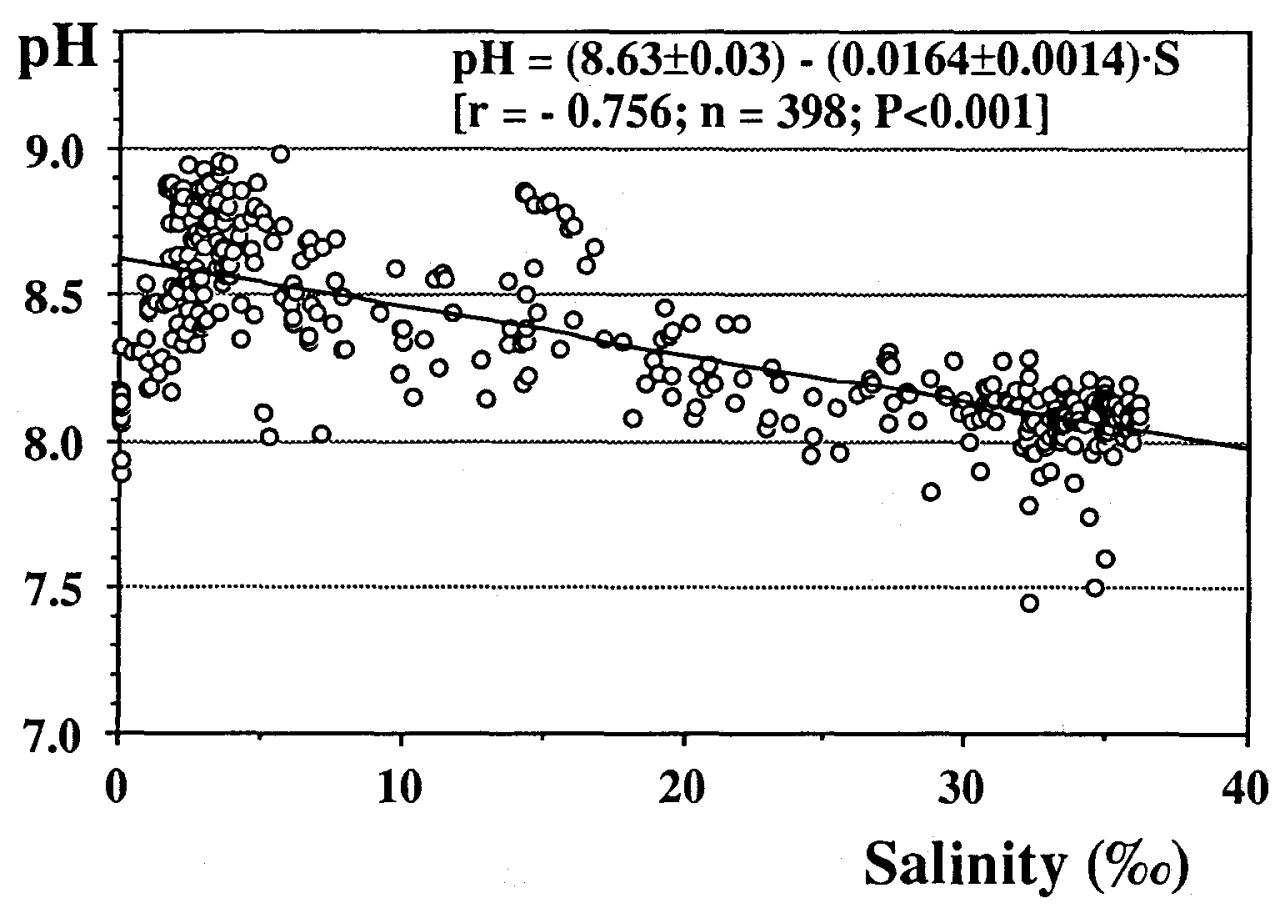

Fig. 3. Relationship between $\mathrm{pH}$ and salinity (S, \%) from November 1991-December 1992 in Mar Chiquita Lagoon, Argentina. r: linear correlation coefficient; n: number of samples; P: level of significance for $r_{i}$ regression coefficient and intercept with the $Y$-axis given with $95 \%$ confidence limits ( \pm )

The first intensive study of tidal cycles was carried out on 17 th-18th November, 1992, taking samples every 3 h over a 30 -h period (Fig. 4). On all later occasions, a longer period $(36 \mathrm{~h})$ and a higher sampling frequency were chosen (mostly every $1-2 \mathrm{~h}$ ). High tide $(120 \mathrm{~cm}$ above the arbitrarily defined zero) was observed in the lagoon approximately at noon on 17 th November. Another, much lower high tide occurred in the adjacent sea at ca 3 a.m., but it did not pass the sandbar in the mouth and, thus, did not influence the hydrographical situation in the lagoon. Salinity decreased during the afternoon ebb tide from euhaline $(36 \%)$ to oligohaline $(<5 \%)$ conditions, then it remained low for at least one day, accompanied by high $\mathrm{pH}$ values (8.3-8.6). Temperature decreased during the night from 18 to $12 \mathrm{C}^{\circ}$; then it increased during the following day to $22.8^{\circ} \mathrm{C}$, due to stagnant conditions in the lagoon. Marine water entering the lagoon with another high tide on 18th November did not influence Sites 2 and 3, because it passed by at close distance as a river-like water mass, pushing brackish water from the interior parts of the lagoon toward the mouth. Hence, in spite of a significant salt water intrusion ( $1 \mathrm{~m}$ increase in water level at Site 2), even the area near the mouth of the lagoon remained under oligohaline conditions for at least two subsequent tidal cycles.

Larvae of the two dominant decapod species, Cyrtograpsus angulatus and Chasmagnathus granulata, were found in low to moderate numbers on both sampling days (Fig. 4). Their individual numbers were at a minimum around both diurnal and nocturnal 
Salinity (\%o) $\left({ }^{\circ} \mathrm{C}\right)$
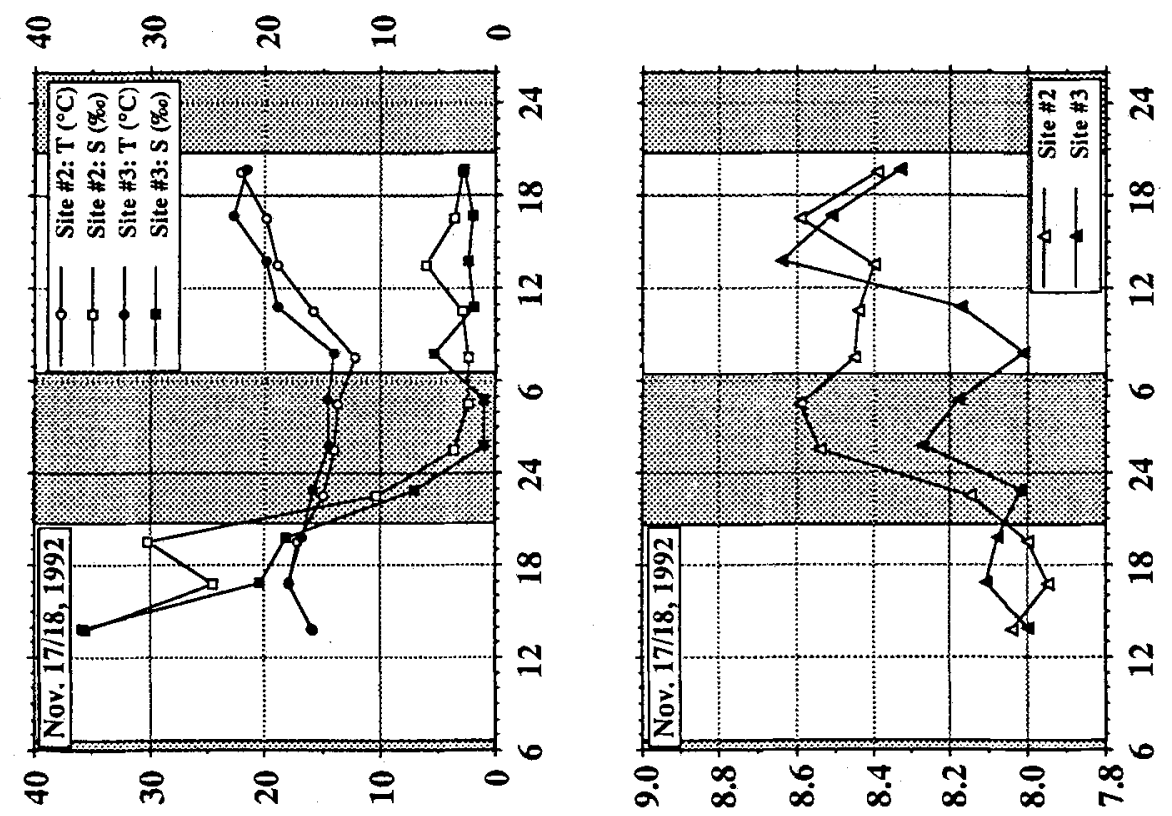

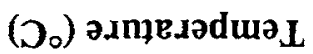

$H^{d}$
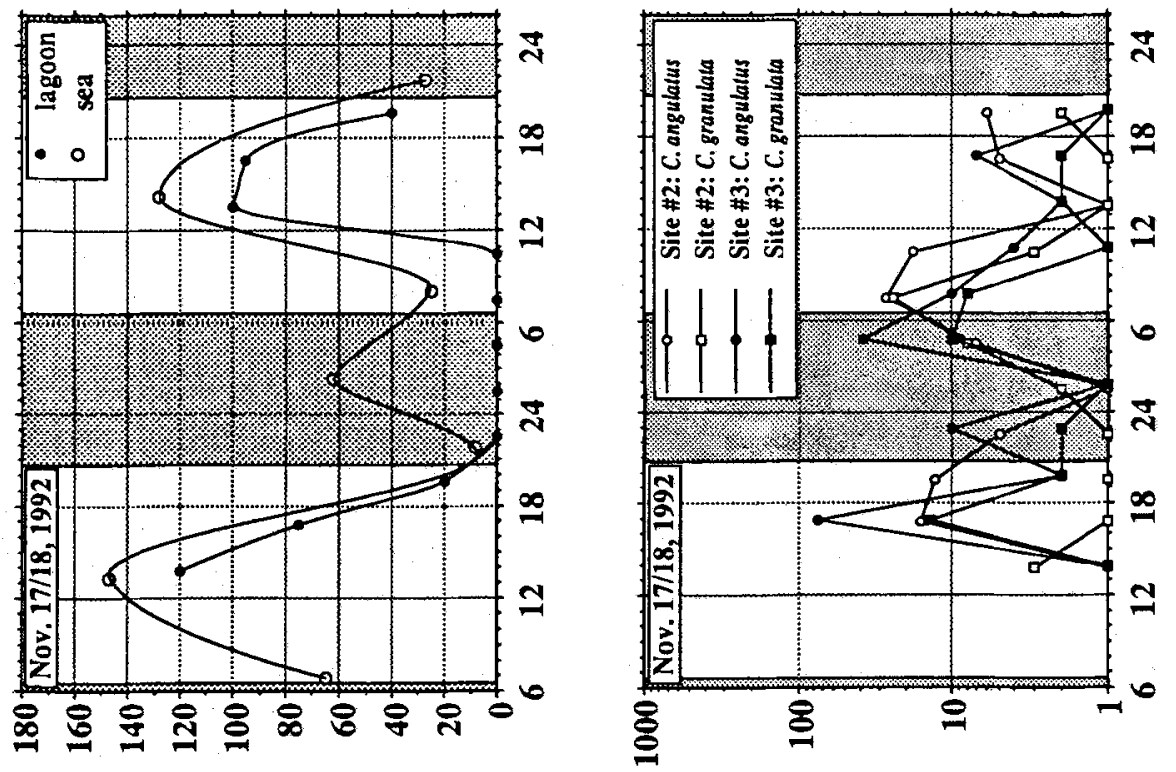

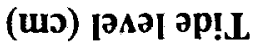

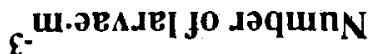

s

gi

의

究

离

ํํㅇ

हี

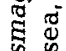

(อ

岁

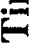

हี่

$3 \stackrel{v}{3}$

के

羟

욜

式营

๑

究客

它

운

要

ั०

-

롴.

灵苛

完完

त

E

룔

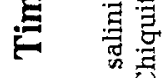

要

总焉

苞

응

$\$$

Ф

Z

串要

ن

它志 
high tides, and they revealed an increasing tendency during the time of a nocturnal ebb tide. The latter is remarkable, since at night there were no changes in water level or hydrographical conditions in the lagoon. Another slight increase in the occurrence of crab larvae was observed on 18th November during the next ebb tide, although only the water level changed, but not the salinity or $\mathrm{pH}$ at the sampling sites.

During the next intensive sampling programme (22nd-23rd November), two tidal cycles with similar amplitudes were observed (Fig.5). However, the hydrographical conditions at the sampling sites were influenced only by the first cycle, with decreasing salinity and increasing $\mathrm{pH}$ values during the evening ebb tide, and followed by rather stagnant conditions thereafter. During the second high tide (6 a. m. on 23rd November), the inflowing marine water passed by, pushing oligohaline water from the interior lagoon toward the mouth. Only at Site 2 was some mixing observed, with mesohaline water $(15 \%)$ occurring there for a short time with maximum water level. Cold weather conditions caused somewhat lower average water temperatures in the lagoon as compared with the previous sampling dates, with a pronounced cycle of relatively low values at night and higher values during the day $\left(12.8\right.$ and $21.0^{\circ} \mathrm{C}$, respectively).

The concentration of crab larvae in the plankton was high (ca 200 to $>1000$ individuals $\cdot \mathrm{m}^{-3}$ ) during the $12 \mathrm{p} . \mathrm{m}$. ebb tide on 22 nd November. It decreased by one order of magnitude during the following afternoon flood tide (Fig. 5). High larval abundance was observed again, when the outflowing tide coincided with the onset of dusk. Larvae disappeared from the plankton later in the night, when the water level increased (without significant changes in hydrographical conditions at the sampling stations). During the next day, larvae occurred exclusively during ebb tides, in general in low numbers.

The situation one week later (29th-30th November) was similar to that observed during the first intensive sampling, with very different amplitudes in subsequent tides (Fig. 6). Again, a weak nocturnal high tide in the sea changed the water level in the lagoon only slightly, and it did not influence the hydrographical conditions at our sampling sites. Unlike the situation during the first sampling, the following high tide (1 p. m. on 30th November) was strong enough (120 cm increase in water level) to replace the brackish water in the study area fully with marine water. Salinity varied during this 36 -h observation period between euhaline $(36 \%)$ and oligohaline $(\leq 3 \%)$, and was accompanied by $\mathrm{pH}$ values varying between 8.0 and 8.9 .

The average concentration of crab larvae in the plankton was higher than on the previous sampling days, including a peak value of almost 8000 Cyrtograpsus angulatus zoeae $\cdot \mathrm{m}^{-3}$ at Site 3 at the beginning of the afternoon ebb tide. There was a rather clear pattern of larval occurrence in this data set, with high individual numbers during ebb tides and low numbers during flood periods. Again, this is remarkable, as the weak nocturnal tide cycle that occurred in the sea did not cause significant changes in water level, salinity, $\mathrm{pH}$, or temperature within the lagoon (Fig. 6).

One week later (6th-7th December), a series of relatively low and similar amplitudes was observed (Fig. 7). In spite of regular changes in the lagoon water level, salinity and $\mathrm{pH}$ at the sampling sites were generally not influenced by tidal currents. Only the first high tide (6th December, 5 p. m.) brought euhaline water for a short time to Site 2 ( $32 \%$, $\mathrm{pH} 8.0)$ and mesohaline water to Site $3(15 \%$, $\mathrm{pH} 8.6)$. All high tides occurring later caused little change in the parameters, thus leaving the study area under mostly 
Salinity (\%o)

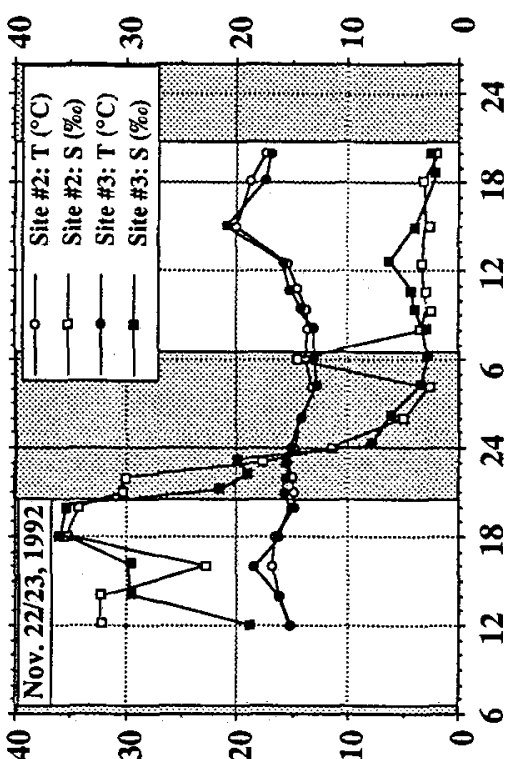

(Do) asnje.əduә,L

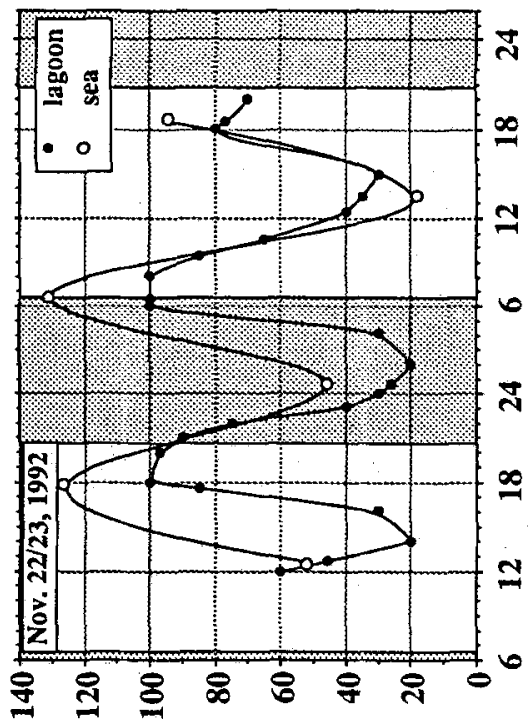

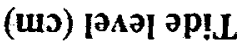

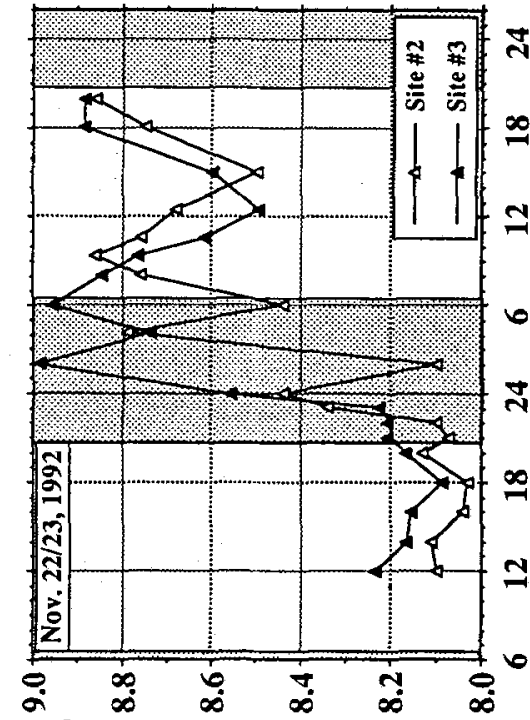

$H^{d}$

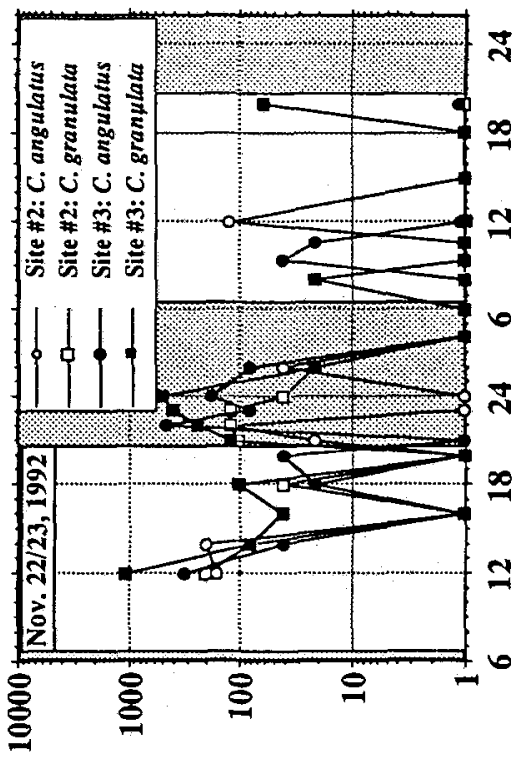

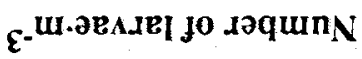

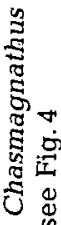

窎

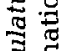

윰

"⿵.

密

ธี

茫

U.

a

要

電

윰 兽

它

包.

已

恶

导

\%

I

胥苛

品

T 1

응

$\stackrel{\square}{\square}$

$\stackrel{Q}{=}$

乐 
Salinity (\%o)

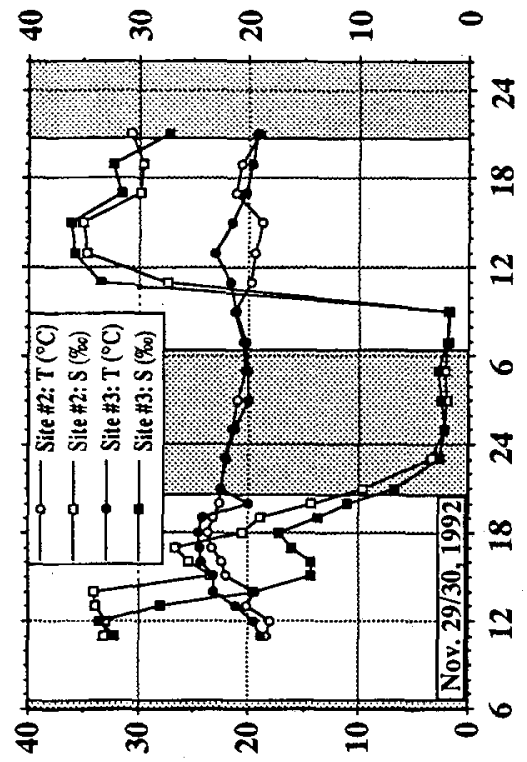

(Do) a.mpesəduaL

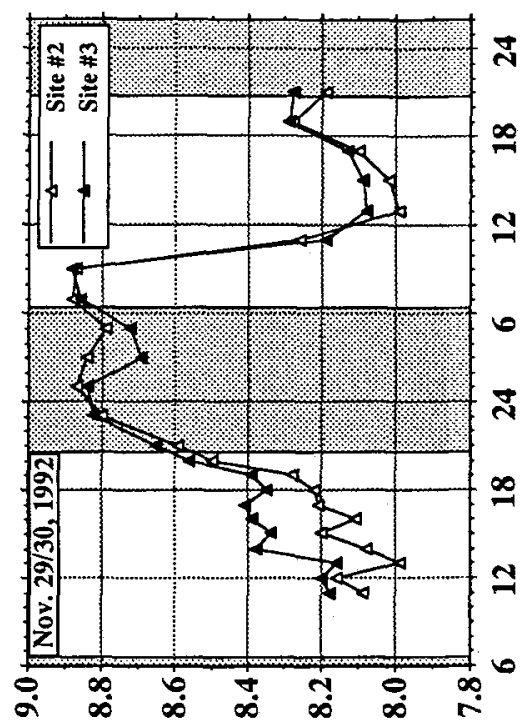

ह



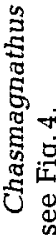

I

完

承

ํํㅇ

엉

范

옹

웜

过

要安

형
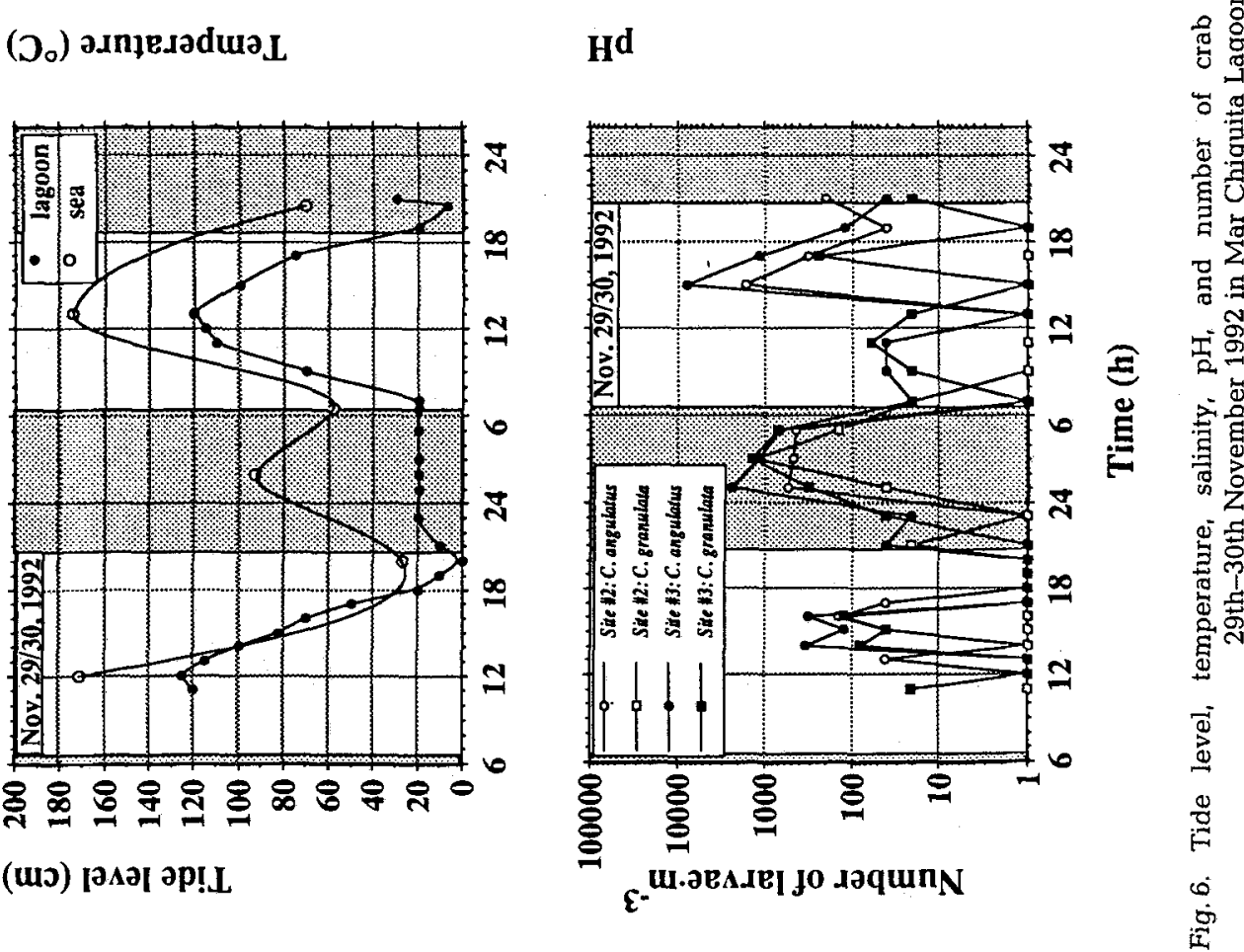

 
Salinity $(\% o)$

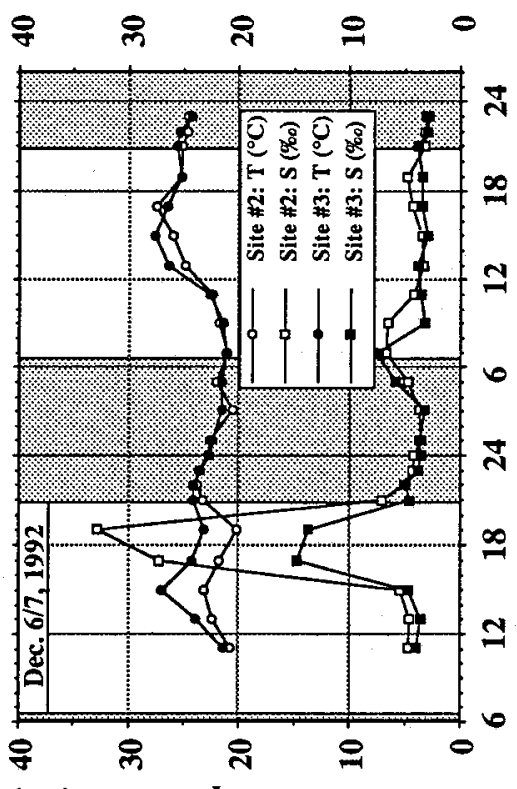

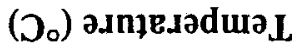
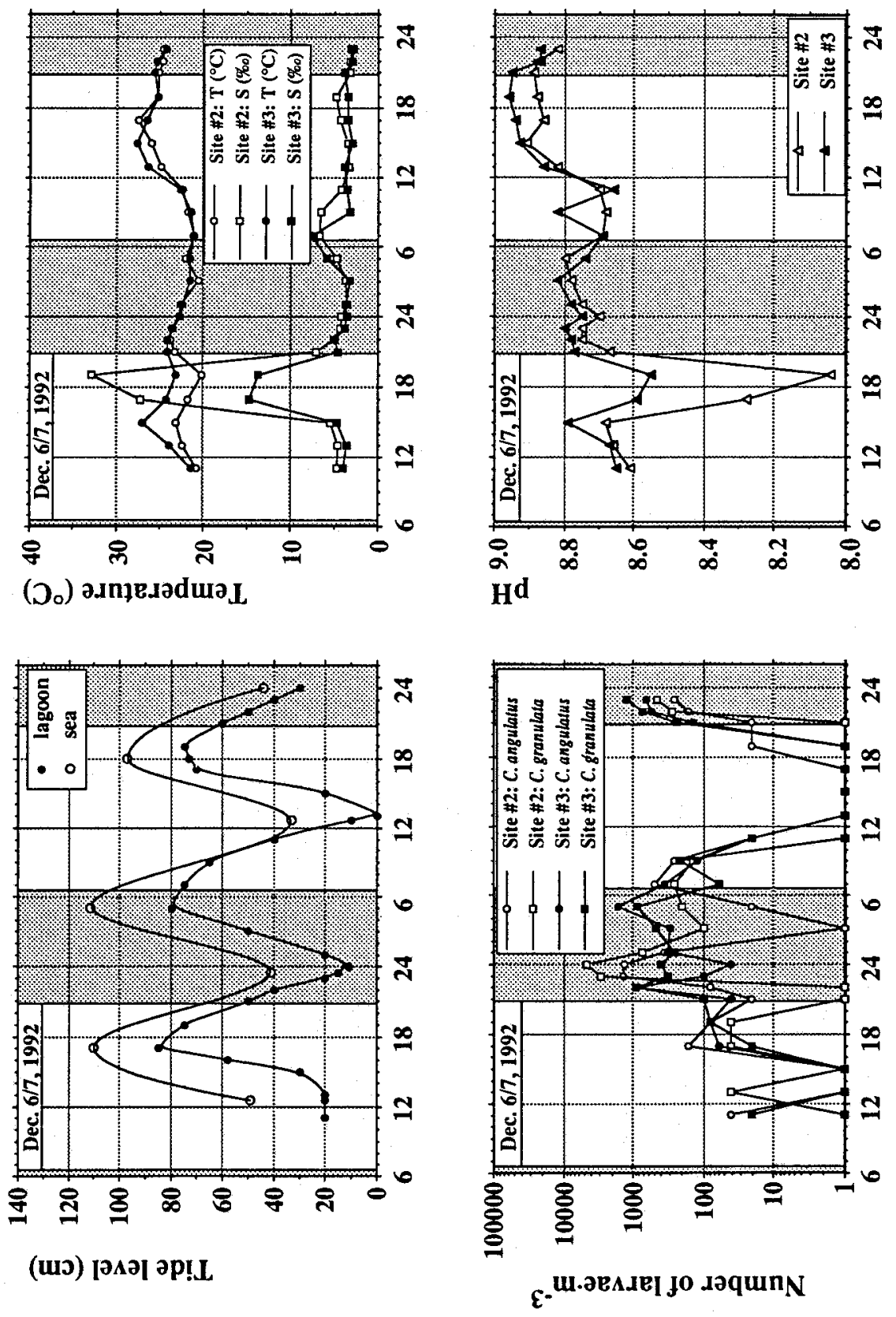

Б

ㅁำ

帘

$\Xi$

导

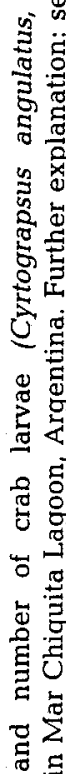

E

异

莺害

ब量

站采

营

:

จ

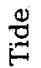

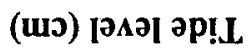


oligohaline conditions. Average temperatures clearly increased, with minimum values $>20$ and a maximum of $27.6^{\circ} \mathrm{C}$ during night and day, respectively.

Only a few crab larvae were found during the afternoon flood tide on 6th December (Fig. 7). They re-appeared in the plankton around high tide (5 p.m.), with an increasing tendency during the evening ebb tide. Larval abundance stayed high during the whole night, although another flood tide entered the lagoon. Apparently, these larvae arrived with oligohaline water masses from the interior parts of the lagoon, pushed toward the mouth by intruding salt water (the latter did not pass our sampling sites directly). No larvae were found in the plankton during a diurnal flood tide on 7 th December. Their number increased drastically during an evening ebb tide that could be registered by a decreasing water level but with no changes in the hydrographical conditions in the lagoon.

\section{Covariation in environmental variables and the occurrence of decapod larvae}

For a statistical analysis of possible influences of external factors on the occurrence of decapod larvae in the lagoon plankton, we grouped our data for the three dominant species (Cyrtograpus angulatus, Chasmagnathus granulata, Palaemonetes argentinus) in three categories of larval abundance: $0,1-299$, and $\geq 300$ individuals $\cdot \mathrm{m}^{-3}$ (Table 1 ). The frequency of other decapod larvae (mostly Plathyxanthus crenulatus) was too low to test for environmental effects.

The percentage values (related to the total number of samples taken at a given condition) indicate that early crab larvae (zoea I) occurred proportionally more frequently (1) when salinities were low or intermediate, (2) during outflowing conditions (ebb tides), and (3) in the night. According to RxC goodness-of-fit G-tests, darkness had the strongest positive effect on the occurrence of larvae $(P<0.001$ in both crab species, $P<0.01$ in shrimp). Frequency of crab larvae was consistently higher during ebb than during flood tides; however, this effect was statistically significant only in Cyrtograpsus angulatus $(\mathrm{P}<0.001)$, but not in Chasmagnathus granulata. In shrimp larvae, an inverse pattern in relation to tidal direction could be observed, but this was not significant.

All crab and shrimp larvae occurred more frequently in water masses with low salinities, but this enhancing effect was in general weaker than that exerted by darkness or outflowing tides; it was statistically significant only in Chasmagnathus granulata and Palaemonetes argentinus $(\mathrm{P}<0.05$ ). Another factor, influencing the frequency of larval crabs was the sampling site (with consistently higher values at Site 3 ; weakly significant only in $C$. granulata, $\mathrm{P}<0.05$ ), but this did not influence the frequency of larval shrimps.

Grouping the data in combinations of the two dominant factors, tidal direction and light condition provides a further illustration of the pattern of crab larvae occurrence (pooled data; see Fig. 8). In consequence of the frequency patterns described above, the most striking difference was found between samples taken during nocturnal ebb tides (combination of favourable conditions) and those during diurnal flood tides (combination of unfavorable conditions). Hardly any difference was found between day/ebb and night/ flood samples, due to mutual compensation of favourable and unfavourable factors in these combinations. When day or night samples are considered exclusively, tides show a significant influence. Likewise, when only flood or only ebb samples are compared, daytime can be recognized as a significant factor. 


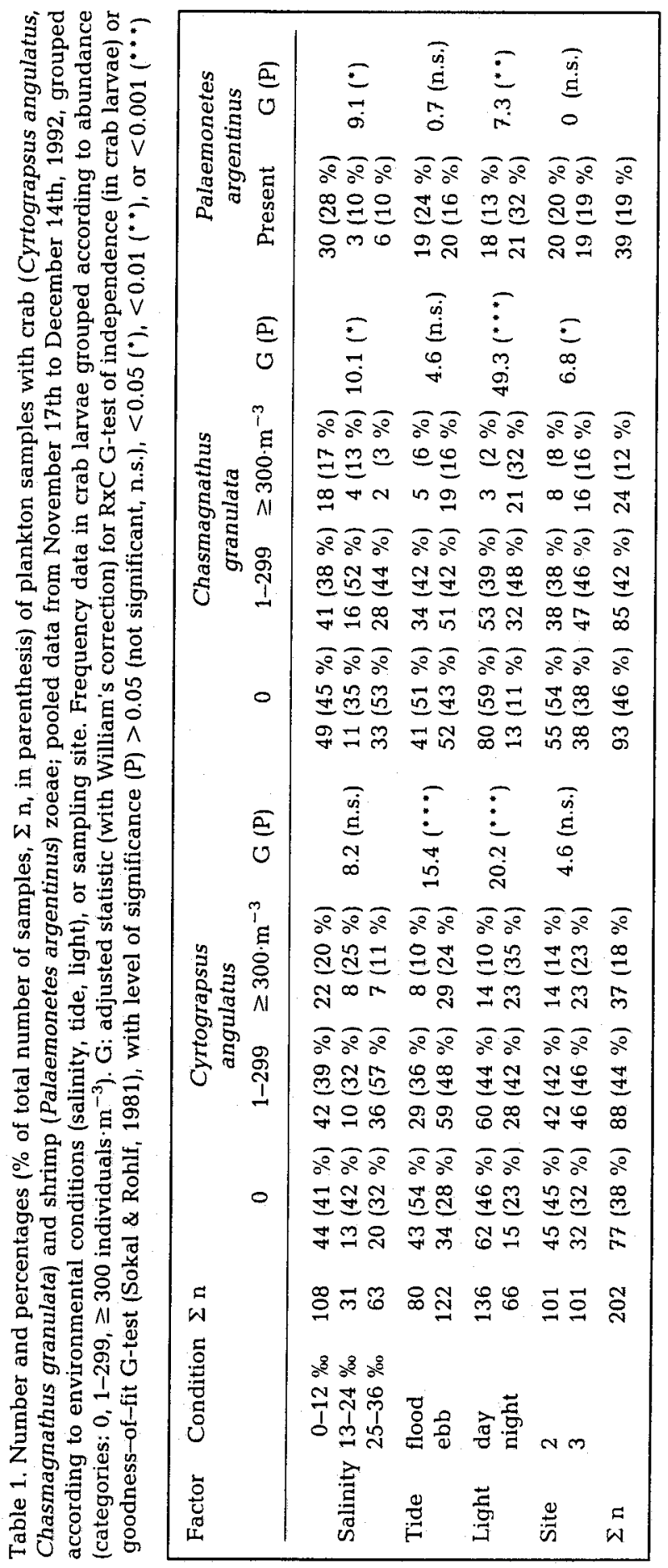




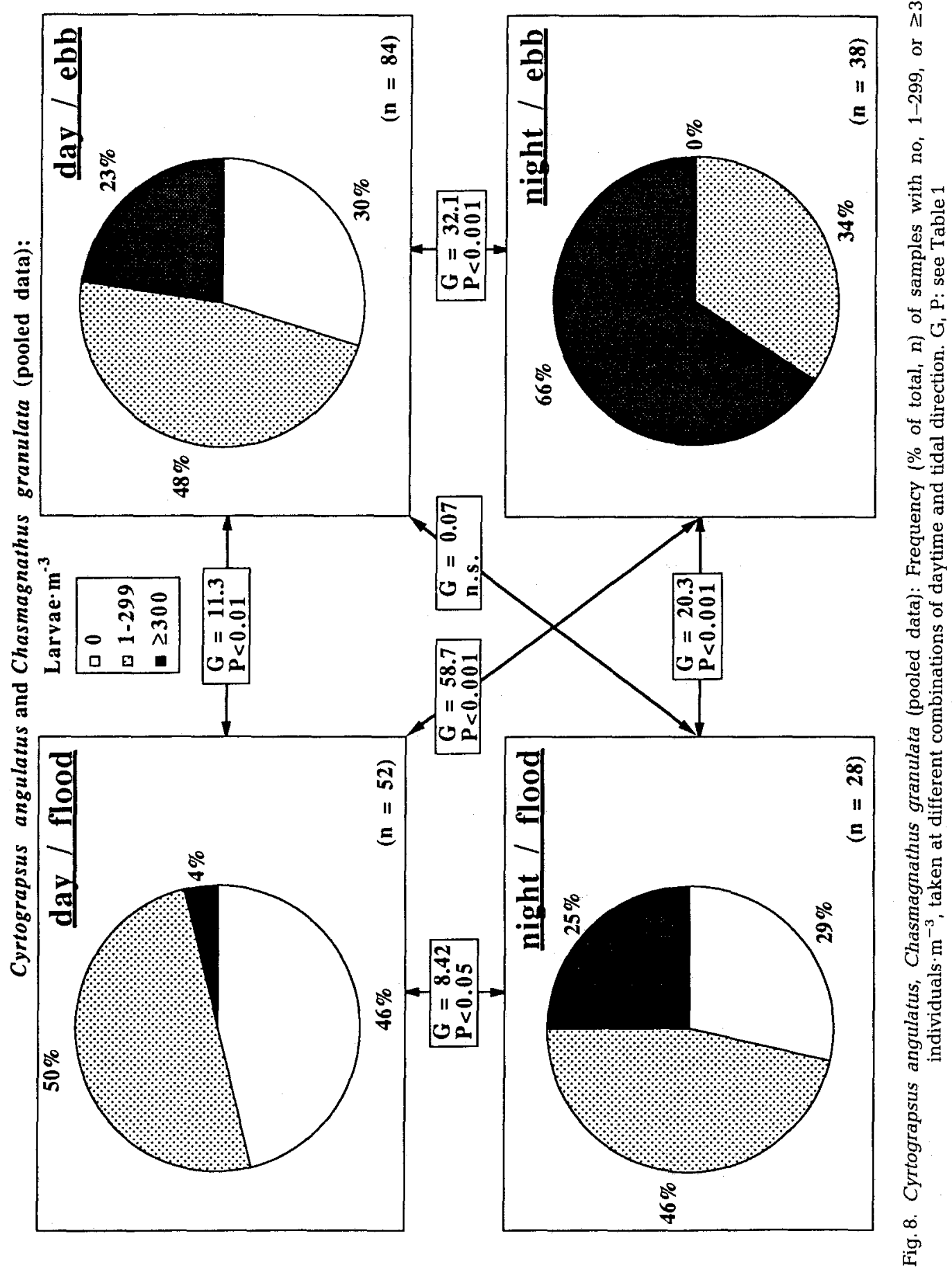




\section{DISCUSSION}

Mar Chiquita Lagoon reveals a complex character, with little predictability of physical conditions. The $\mathrm{pH}$ was found negatively correlated with salinity, probably as a result of particularly high primary production in fresh and brackish water. However, our data may indicate a positive correlation in the salinity range $<5 \%$. The relationship between $\mathrm{pH}$ and salinity may vary during the course of the year, due to variation in phytoplankton production. Hence, more detailed hydrographical and planktological studies may prove whether $\mathrm{pH}$ can be used as an additional indicator for the identification of water masses in this brackish lagoon. As a further criterion, future investigations should include quantitative information on the composition of plankton communities.

In a total of 398 samples taken during the course of one year, a crab zoea at a stage later than zoea-I was never found, and almost all of these early zoeae had an empty stomach, despite the presence of dense phyto- and zooplankton populations available as a potential food source. The lagoon water had a dark green colour due to rich phytoplankton (mostly flagellates, but also diatoms), and most of our samples contained high numbers of copepods, cladocerans, and ostracods (not quantified; but total holozooplankton density was estimated at least one to two orders of magnitude higher than larval abundance). These observations suggest that the larvae did not have enough time for food uptake after hatching from the egg. Moreover, not one single zoea caught in the lagoon had developed beyond moult-cycle stage $\mathrm{C}$, which should be reached within about one day after hatching (Anger, 1987).

It can be concluded from these data that the larvae of the two dominating euryhaline crab species, Cyrtograpsus angulatus and Chasmagnathus granulata, follow the export type strategy of dispersal and recruitement: freshly hatched zoea I larvae leave their parent environmental very rapidly (normally within $<1$ day) and then spend the rest of their zoeal development in adjacent continental shelf waters of the southwestern Atlantic Ocean. On days without an exchange of water between the lagoon and the sea, freshly hatched crab larvae may survive, without developing any further, until they can leave the lagoon with a later ebb tide. Moribund and dead larvae found in stagnant water masses with low salinity $(<5 \%$ ) show that the larvae will die, when tidal height remains low over an extended period. This is corroborated by laboratory experiments on larval tolerance of C. granulata (Anger, unpubl.), suggesting that the zoea I may survive in $5 \%$ for a few days, but probably not in lower salinities. This physiological weakness of early ontogenetic stages should select for an export rather than a retention strategy.

The export mechanism of crab species in Mar Chiquita Lagoon must be based upon a control of the egg hatching process, leading to increased hatching activity during favourable export conditions, especially during nocturnal ebb tides. Exclusive hatching at specific times in diel, tidal, semilunar, or lunar cycles had been observed in several estuarine crabs and other invertebrates (Naylor, 1976; Saigusa \& Hidaka, 1978; DeCoursey, 1979; Forward et al., 1982; DeVries et al., 1983b; DeVries \& Forward, 1989). Larval release rhythms are entrained by cyclic changes in environmental factors such as salinity and submarine irradiance level (Forward et al., 1986; Forward, 1987). The timing of the hatching process is controlled by chemical communication between the eggs and the female, i.e. by the action of pheromones that are released from ripe eggs and stimulate pumping behaviour in females (Forward \& Lohmann, 1983; Rittschof et al., 
1985, 1989). Pumping, on the other hand, may stimulate the release of proteolytic enzymes by the embryos and, thus, synchronize the fracture of egg membranes and, hence, the hatching of larvae (DeVries \& Forward, 1991a, b).

Hatching intensity in Mar Chiquita Lagoon often increased during those ebb tides which occurred only in the adjacent sea but did not reach the lagoon, in particular when these tides were nocturnal. Lack of environmental stimuli in the water, for instance, changes in salinity, $\mathrm{pH}$, temperature, sometimes even in water level, suggests that there is a persisting endogenous hatching rhythm. Such endogenous rhythms exist also in larval migration behaviour of crabs; they can be exogenously entrained during late embryonic development and persist in the zoea I stage for an extended period of time, even under constant laboratory conditions (Cronin \& Forward, 1979). Christy \& Stancyk (1982), who also observed tidal and diel hatching rhythms in estuarine crab larvae, concluded that "the timing of larval release may result in rapid seaward transport of newly hatched zoeae on nocturnal ebb tides ... leading to significant net export from the estuary", i. e. the control of hatching and its coordination with cyclic changes in environmental conditions should be an important component of the export mechanism. This applies not only to Cyrtograpsus angulatus and Chasmagnathus granulata, but probably also to all other brachyuran species in Mar Chiquita Lagoon.

As an alternative explanation of our data, reviewers of an earlier version of this paper suggested an escape of crab zoeae from sampling due to extremely fast, $100 \%$ efficient, downward migration. However, not only has such behaviour never been observed, but is most unlikely for the following reasons. The lagoon is very shallow (maximum depth: $1.2 \mathrm{~m}$ below mean spring low tide, or ca $3 \mathrm{~m}$ at spring high tide), so that little or no vertical stratification can be expected. Instead, complicated patterns of horizontally coexisting water masses occur, with different hydrological character and current direction. In relatively slow swimming plankton organisms, such as crab zoeae, it is extremely unrealistic to assume that all of the missing stages (II-IV in Chasmagnathus granulata, II-V in Cyrtograpsus angulatus; Boschi et al., 1967; Scelzo \& Lichtschein, 1979) could escape from sampling, if they developed in the lagoon. In order to hide in deeper water, they would first have to migrate horizontally (crossing different water masses), from the wide shallow reaches of the lagoon where they hatch $\leq 1 \mathrm{~m}$ depth) to the few existing narrow tide channels, or they would have to stay exclusively very near the bottom. Moreover, such an unlikely behaviour would have to occur exclusively (not a single individual was caught!) during a time span of a whole year, including all daytimes, tides, and sampling sites (during our preliminary survey, 7 sites were sampled). In summary, we conclude that rapid export of larval crabs is the only plausible explanation for the data presented here.

Occasional occurrence of crab megalopae in the plankton suggests that the larvae eventually return in this stage from coastal waters into the lagoon for settlement and metamorphosis, more than likely with incoming flood tides. The same strategy is most probably followed by the mud crab, Plathyxanthus crenulatus, the fiddler crab, Uca urugayensis, and the grapsid rock crab, Cyrtograpsus altimanus, but not by the palaemonid shrimp, Palaemonetes argentinus. Larvae of the latter species occurred in all development stages inside the lagoon, including various zoeal, decapodid, and juvenile instars, giving evidence of an alternative strategy, i. e. retention in the lagoon.

The average level of larval abundance in the plankton increased during the sampling 
period from November to December. This increase in hatching intensity coincides with increasing temperatures in late spring, and it reflects an increasing reproductive activity during this period. Bas et al. (in prep.) found in Mar Chiquita Lagoon significantly increasing numbers of ovigerous crab females from October through December. Thus, relatively low numbers of megalopae in the plankton may indicate that the recruitment season was only beginning. Increasing numbers of ingressing megalopa larvae should be expected one or two months later.

Adults of both Cyrtograpsus angulatus and Chasmagnathus granulata live in dense populations in the inner parts of the lagoon, where salinity and other environmental factors are highly variable, often governed by oligohaline, almost freshwater conditions (Spivak et al., 1994). Unlike the situation in some other estuarine crabs, for instance in Callinectes species (Smyth, 1980; Epifanio \& Dittel, 1982; DeVries et al., 1983a; Millikin \& Williams, 1984), no evidence of downstream migration of ovigerous females was found in decapod crustaceans of Mar Chiquita Lagoon. As a consequence of the local distribution pattern of reproducing adults, freshly hatched larvae of $C$. granulata were significantly more frequent in oligohaline water masses than in higher salinities, and more frequent at sampling Site 3 than at Site 2. Site 3 is close to a Spartina salt marsh that is inhabited by a particularly dense population of this species (Spivak et al., 1994).

Shrimp larvae were also found with significantly higher frequency in low salinities. However, this cannot be explained by local distribution of the adults alone, since also later larval stages were found mostly in oligohaline water. Apparently, adult and larval Palaemonetes argentinus live in the same environment, including "fresh-water" creeks (with a salinity of about $1 \%$ ); however both avoid polyhaline and euhaline waters. This accords with preliminary cultivation experiments in the laboratory (Spivak, unpubl.) which have shown that $P$. argentinus larvae can develop in a wide range of salinities (from $<1$ to $>30 \%$ ), but seawater may cause increased mortality and delayed development. Thus, $P$. argentinus is not a euryhaline marine, but a true brackish-water species sensu Remane (1971).

Retention mechanisms are based on endogenously controlled larval migrations that, like hatching rhythms, are entrained and modified by environmental changes (Cronin \& Forward, 1979, 1980, 1982, 1983). The interaction of several exogenous stimuli may cause complex vertical migration patterns that eventually ensure a retention of the larvae at depths with no net flow (Cronin, 1982; Cronin \& Forward, 1986). Such behavioural adaptations to life in a cyclically changing environment should also play a significant role in Palaemonetes argentinus larvae. Since these were found to develop through all stages within the brackish lagoon system, their scarce occurrence in day samples, even in those from oligohaline water masses, suggests that they had migrated downward and stayed during daylight near the bottom. Sandifer (1975) also found larvae of species with a retention strategy (among them a North American Palaemonetes) more frequently near the bottom, where net flow was zero or upstream. This mechanism is possible in shrimp larvae, because they are, particularly at later developmental stages, much more rapid swimmers than crab zoeae; in the laboratory, they were often seen to exhibit a semibenthic behaviour.

What are the driving forces that favour the evolution of complex larval migration patterns or egg hatching rhythmicity, and what are the major advantages or disadvantages of those alternative strategies of dispersal and recruitment? Osmotic stress, which is 
one of the principal problems of estuarine organisms, certainly selects for export mechanisms. This appears to be the case, at least in Chasmagnathus granulata (larval salinity tolerance in other species remains to be determined experimentally). On the other hand, Morgan (1987a) showed that some species with an export type of development may have very tolerant larvae and, as evidenced by species that retain their larvae in brackish water, estuarine species are in principle able to evolve physiological mechanisms of osmotic resistance or regulation. In a stratified water column, downward migrations could be explained as an escape from osmotic stress. However, physiologically tolerant shrimp larvae may also carry out vertical migrations. In this case, the latter cannot be described as a necessity to avoid low salinity stress, since vertical stratification is unlikely to happen in a shallow lagoon such as Mar Chiquita.

As an alternative (or additional) explanation for the evolution of vertical migrations, escape from high predation pressure has been suggested (Zaret \& Suffern, 1976; Stich \& Lampert, 1981; Gliwicz, 1986). The same applies to the evolution of complicated export mechanisms (Morgan, 1987b). Planktivorous fish, particularly small species and developmental stages, are known to concentrate in estuaries, especially in summer, when decapod larvae are most frequent in the plankton (McErlean et al., 1972; Subrahmanyam \& Drake, 1975; Crabtree \& Dean, 1982). This is most probably the case in Mar Chiquita Lagoon, where recreational fisheries sustain a significant summer tourism in the area. Especially high abundances of planktivorous larval and juvenile fishes were observed in brackish salt marshes similar to those of Mar Chiquita Lagoon (Cain \& Dean, 1976; Weinstein, 1979). High abundances of small fishes can have considerable impact on estuarine zooplankton communities (Thayer et al., 1974; Bengston, 1984) and exert great adaptive pressure on decapod crustaceans, whose larvae encounter the greatest risk of fish predation in the upper part of estuaries (Morgan, 1987b).

The latter investigation presented evidence from both field and laboratory observations that decapod species with an export type of development were more vulnerable to predation that those which show a retention strategy. Besides behavioural mechanisms that reduce the probability of encountering planktivorous fishes, there are post-contact defense mechanisms such as passive sinking or escape by enhanced body size (Morgan, 1987b). The latter may be achieved by formation of long carapace spines (in crab larvae), or by large overall body size (in shrimp, Palaemonetes, larvae). P. argentinus has large larvae and, additionally, it may avoid visually directed predators by means of vertical migrations, staying near the bottom during daylight. Nocturnal ascent to the surface may be related to larval feeding activity.

The costs for the evolution of a strategy which ensures development in the parent habitat and avoids a potentially irreversible transport to unsuitable marine environments should be the need for a concurrent evolution of enhanced physiological resistance to osmotic stress and predation in shrimp larvae. Cyrtograpsus angulatus and Chasmagnathus granulata larvae, are in contrast probably much less resistant to low and rapidly changing salinities, and they are very small, have short carapace spines and hence, may be more vulnerable to predation. The evolution of an efficient export mechanism based on the control of egg hatching rhythms represents a suitable alternative strategy for the avoidance of both high physiological stress and predation pressure. It allows successful recruitment in harsh estuarine environments and, additionally, offers the advantage of a greater horizontal dispersal in a wide geographical area. 
Acknowledgements. This paper was written as part of a German-Argentine cooperative programme ("MAR-4") between the Biologische Anstalt Helgoland (BAH) and the Universidad Nacional de Mar del Plata (UNMdP). It was funded by the International Bureau of the Alfred-Wegener-Institut (AWI, Bremerhaven; on behalf of the German Federal Ministry of Science and Technology, BMFT, Bonn), the Secretaría de Ciencia y Tecnología (SECYT, Buenos Aires), the UNMdP (grant OCS 091/92; 95), and the CONICET (Consejo Nacional de Investigaciones Científicas y Técnicas, República Argentina; grant PIA 0059/92).

\section{LITERATURE CITED}

Anger, K., 1983. Moult cycle and morphogenesis in Hyas araneus larvae (Decapoda, Majidae), reared in the laboratory. - Helgoländer Meeresunters. 36, 285-302.

Anger, K., 1987. The $\mathrm{D}_{\mathrm{o}}$ threshold: a critical point in the larval development of decapod crustaceans. J. exp. mar. Biol. Ecol. 108, 15-30.

Bengston, D. A., 1984. Resource partitioning by Menidia menidia and Menidia beryllina (Osteichthyes: Atherinidae). - Mar. Ecol. Prog. Ser. 18, 21-30.

Boschi, E. E., 1964. Los crustáceos decápodos Brachyura del litoral bonaerense (R. Argentina). - Boln Inst. Biol. mar., Mar del Plata 6, 1-100.

Boschi, E. E., 1981. Larvas de crustacea decapoda. In: Atlas del zooplancton del Atlántico Sudoccidental. Ed. by D. Boltovskoy. INIDEP, Mar del Plata, 699-758.

Boschi, E. E., 1988. El ecosistema estuarial del Rio de la Plata (Argentina y Uruguay). - An. Inst. Cienc. Mar Limnol. Univ. nac. autón. México 15, 159-182.

Boschi, E. E., Scelzo, M. A. \& Goldstein, B., 1967. Desarrollo larval de dos especies de Crustáceos Decápodos en el laboratorio. Pachycheles haigae Rodrigues Da Costa (Porcellanidae) y Chasmagnathus granulata Dana (Grapsidae). - Boln Inst. Biol. mar., Mar del Plata 12, 3-46.

Bundesamt für Seeschiffahrt und Hydrographie (Ed.) 1991. Nautisches Jahrbuch oder Ephemeriden und Tafeln für das Jahr 1992 zur Bestimmung der Zeit, Länge und Breite auf See nach astronomischen Beobachtungen. - Naut. Jb., Hamb. 141, 1-45.

Cain, R. L. \& Dean, J. M., 1976. Annual occurrence, abundance and diversity of fish in a South Carolina intertidal creek. - Mar. Biol. 36, 369-379.

Christy, J. H. \& Stancyk, S. E., 1982. Timing of larval production and flux of invertebrate larvae in a well-mixed estuary. In: Estuarine comparisons. Ed. by V. S. Kennedy. Acad. Press, New York, 489-503.

Crabtree, R. E. \& Dean, J. M., 1982. The structure of two South Carolina estuarine tide pool fish assemblages. - Estuaries 5, 2-9.

Cronin, T. W., 1982. Estuarine retention of larvae of the crab Rhithropanopeus harrisii. - Estuar. coast. Shelf Sci. 15, 207-220.

Cronin, T. W. \& Forward, R. B., 1979. Tidal vertical migration: an endogenous rhythm in estuarine crab larvae. - Science, N. Y. 205, 1020-1022.

Cronin, T. W. \& Forward, R. B., 1980. The effects of starvation on phototaxis and swimming of larvae of the crab Rhithropanopeus harrisii. - Biol. Bull. mar. biol. Lab., Woods Hole 158, 283-294.

Cronin, T. W. \& Forward, R. B., 1982. Tidally timed behaviour: effects on larval distributions in estuaries. In: Estuarine comparison, Ed. by V. S. Kennedy. Acad. Press, New York, 505-520.

Cronin, T. W. \& Forward, R. B., 1983. Vertical migration rhythms of newly hatched larvae of the estuarine crab, Rhithropanopeus harrisii. - Biol. Bull. mar. biol. Lab., Woods Hole 165, 139-153.

Cronin, T. W. \& Forward, R. B., 1986. Vertical migration cycles of crab larvae and their role in larval dispersal. - Bull. mar. Sci. 39, 192-201.

DeCoursey, P. J., 1979. Egg hatching rhythms in three species of fiddler crabs. In: Proceedings of the 13th European Marine Biology Symposium. Ed. by E. Naylor \& R. G. Hartnoll. Pergamon Press, Oxford, 399-406.

DeVries, M. C. \& Forward, R. B., 1989. Rhythms in larval release of the sublittoral crab Neopanope sayi and the supralittoral crab Sesarma cinereum (Decapoda; Brachyura). - Mar. Biol. 100, 241-248.

DeVries, M. C. \& Forward, R. B., 1991a. Control of egg-hatching time in crabs from different tidal heights. - J. crust. Biol. 11, 29-39. 
DeVries, M. C. \& Forward, R. B., 1991b. Mechanisms of crustacean egg hatching: evidence for enzyme release by crab embryos. - Mar. Biol. 110, 281-291.

DeVries, M. C., Epifanio, C. E. \& Dittel, A. I., 1983a. Reproductive periodicity of the tropical crab Callinectes arcuatus Ordway in Central America. - Estuar. coast. Shelf Sci. 17, 709-716.

DeVries, M. C., Epifanio, C. E. \& Dittel, A. I., 1983b. Lunar rhythms in the egg hatching of the subtidal crustacean: Callinectus arcuatus Ordway (Decapoda: Brachyura). - Estuar. coast. Shelf Sci. $17,717-724$.

Drach, P., 1939. Mue et cycle d'intermue chez la Crustacés décapodes. - Annls Inst. océanogr, Monaco 19, 103-391.

Epifanio, C. E. \& Dittel, A. I., 1982. Comparison of dispersal of crab larvae in Delaware Bay, USA, and the Gulf of Nicoya, Central America. In: Estuarine comparisons. Ed. by V. S. Kennedy. Acad. Press, New York, 477-487.

Fasano, J. L., Hernández, M. A., Isla, F. I. \& Schnack, E. J., 1982. Aspectos evolutivos y ambientales de la laguna Mar Chiquita (provincia de Buenos Aires, Argentina). - Oceanologica Acta 1982 (Nr. spéc.), 285-292,

Forward, R. B., 1987. Larval release rhythms of decapod crustaceans: an overview. - Bull. mar. Sci. $41,165-176$.

Forward, R. B. \& Lohmann, K. J., 1983. Control of egg hatching in the crab Rhithropanopeus harrisii (Gould). - Biol. Bull. mar. biol. Lab., Woods Hole 165, 154-166.

Forward, R. B., Lohmann, K. \& Cronin, T. W., 1982. Rhythms in larval release by an estuarine crab (Rhithropanopeus harrisii). - Biol. Bull. mar. biol. Lab., Woods Hole 163, 287-300.

Forward, R. B., Douglass, J. K. \& Kenney, B. E., 1986. Entrainment of the larval release rhythm of the crab Rhithropanopeus harrisii (Brachyura: Xanthidae) by cycles in salinity change. - Mar. Biol. $90,537-544$.

Gliwicz, Z. M., 1986. A lunar cycle in zooplankton. - Ecology 67, 883-898.

Hartnoll, R. G., 1988, Evolution, systematics, and geographical distribution. In: Biology of the land crabs. Ed. by W. W. Burggren \& B. R. McMahon. Cambridge Univ. Press, New York, 6-54.

McErlean, A. J., O'Conner, S. G., Milhursky, J. A. \& Gibson, C. I., 1972. Abundance, diversity and seasonal patterns of estuarine fish populations. - Estuar. coast. mar. Sci. 1, $19-36$.

Menú-Marque, S. A., 1973. Desarrollo larval de Palaemonetes argentinus (Nobili, 1901) en el laboratorio (Crustacea, Caridea, Palaemonidae). - Physis, B. Aires (Sec. B) 32, 149-169.

Millikin, M. R. \& Williams, A. B., 1984. Synopsis of biological data on the blue crab, Callinectes sapidus Rathbun. - NOAA Tech. Rep. NMFS 1, 1-39.

Morgan, S. G., 1987a. Adaptive significance of hatching rhythms and dispersal patterns of estuarine crab larvae: avoidance of physiological stress by larval export? - J. exp. mar. Biol. Ecol. 113, $71-78$.

Morgan, S. G., 1987b. Morphological and behavioral antipredatory adaptations of decapod zoeae. Oecologia 73, 393-400.

Naylor, E., 1976. Rhythmic behaviour and reproduction in marine animals. In: Adaptation to environment. Ed. by R. R. Newell. Butterworth, London, 393-429.

Olivier, S., Escofet, A., Penchaszadeh, P. \& Orensanz, J., 1972. Estudios ecológicos de la región estuarial de Mar Chiquita (Bs. As. Argentina). I. Las comunidades bentónicas. - An. Soc. cient. Argent. 193, 237-262.

Remane, A., 1971. Ecology of brackish water. In: Biology of brackish water. Ed. by A. Remane \& C. Schlieper. Wiley, New York, $210 \mathrm{pp}$.

Rittschof, D., Forward, R. B. \& Mott, D., 1985. Larval release in the crab Rhithropanopeus harrisii (Gould): chemical cues from hatching eggs. - Chem. Senses 10, 567-577.

Rittschof, D., Forward, R. B., Simons, D. A., Reddy, P. A. \& Erickson, B. W., 1989. Peptide analogs of the mud crab pumping pheromone: structure-function studies - Chem. Senses 14, 137-148.

Saigusa, M. \& Hidaka, T., 1978. Semilunar rhythm in the zoea-release activity of the land crabs Sesarma. - Oecologia 37, 163-176.

Sandifer, P. A., 1973. Distribution and abundance of decapod crustacean larvae in the York River estuary and adjacent lower Cheaspeake Bay, Virginia, 1968-1969. - Chesapeake Sci. 14, 235-257.

Sandifer, P. A., 1975. The role of pelagic larvae in recruitment to populations of adult decapod crustaceans in the York River estuary and adjacent lower Chesapeake Bay, Virginia. 3, 269-279. 
Scelzo, M. A. \& Lichtschein, V. B., 1979. Desarrollo larval y metamórfosis del cangrejo Cyrtograpsus altimanus Rathbun, 1914 (Brachyura, Grapsidae) en laboratorio, con observaciones sobre la ecología de la especie. - Physis, B. Aires (Sec. A) 38, 103-126.

Smyth, P. O., 1980. Callinectes (Decapoda: Portunidae) larvae in the Middle Atlantic Bight, 1975-77. Fish. Bull. U.S. 78, 251-265.

Sokal, R. R. \& Rohlf, F. J., 1981. Biometry. Freeman, San Francisco, 859 pp.

Spivak, E., Anger, K., Luppi, T. Bas, C. \& Ismael, D., 1994. Distribution and habitat preferences of two grapsid crab species in Mar Chiquita Lagoon (Province of Buenos Aires, Argentina). Helgoländer Meeresunters. 48, 59-78.

Stich, H. B. \& Lampert, W., 1981. Predator evasion as an explanation of diurnal vertical migration by zooplankton. - Nature, Lond. 293, 396-398.

Subrahmanyam, C. B. \& Drake, S. H., 1975. Studies on the animal communities in two north Florida salt marshes. - Bull. mar. Sci. 25, 445-465.

Thayer, G. W., Hoss, D. E., Kjelson, M. A., Hettler, W. F. \& Lacroix, M. W., 1974. Biomass of zooplankton in the Newport River estuary and the influence of post-larval fishes. - Chesapeake Sci. 15, 9-16.

Truesdale, F. M. \& Adryszak, B. L., 1983. Occurrence and distribution of reptant decapod crustacean larvae in neritic Louisiana waters: July 1976. - Contr. mar. Sci. 26, 37-53.

Weinstein, M. P., 1979. Shallow marsh habitats as primary nurseries for fishes and shellfish, Cape Fear River, North Carolina. - Fish Bull. U. S. 77, 339-356.

Zaret, T. M. \& Suffern, J. S., 1976. Vertical migration in zooplankton as a predator avoidance mechnism. - Limnol. Oceanogr. 21, 804-813. 